Dept. of Theriogenology,

Fac. of Vet. Med., Assiut University,

Head of Dept. Prof. Dr. M. Abdel-Rouf.

\title{
OESTRADIOL AND PROGESTERONE LEVELS IN THE SERUM OF SHE-CAMEL AS RELATED TO DIFFERENT OVARIAN STRUCTURES
}

(With Two Tables)

\author{
By
}

\section{A.H. ZAGHLOUL and S.H. SHEHATA}

(Received at 10/6/1991)

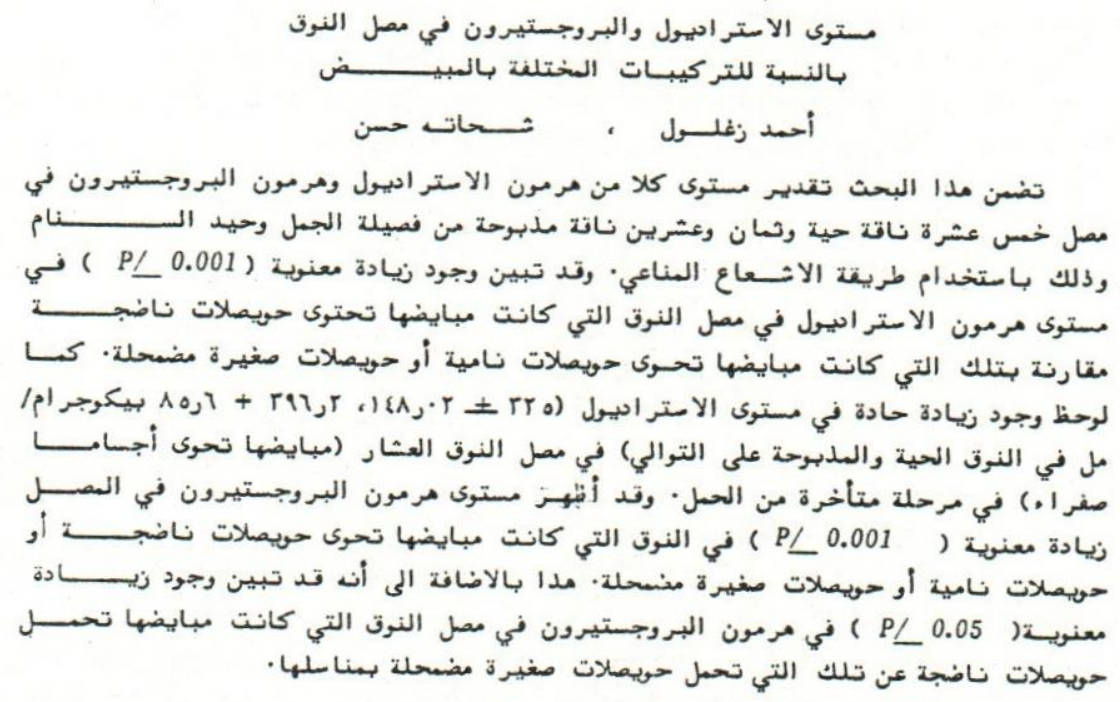

\section{SUMMARY}

Oestradiol and progesterone levels were estimated, using radioimmunoassay, in the sera of 15 living and 28 slaughtered adult she-camels (Camelus dromedarius) having different structurs in their ovaries. A significant $(P / 0.001)$ increase of oestradiol level was observed in the sera of Shecamels having mature follicles than those having growing follicles or small atretic follicles in their ovaries. A sharp increase of oesteradiol level $(325.0 \pm 148.02$ and $396.2 \pm 85.6 \mathrm{pg} / \mathrm{ml}$ in living and slaughtered animals, respectively) was noticed in the sera of pregnant animals (with corpora lutea in their ovaries) at late stage of pregnancy. Serum progesterone level showed a significant $(P / 0.001)$ increase in she-camels having corpora lutea (pregnant or non- pregnant) than those having mature follicles or growing follicles or small atretic follicles in their ovaries. A significant $(P / 0.05)$ increase of progesterone level was also observed in the sera of animals with mature follicles than those with small atretic follicles in their gonads. 


\section{ZAGHLOUL \& SHEHATA}

\section{INTRODUCTION}

Until approximately 10 years ago, reproductive endocrinology and the hormonal profile of the she-camel (Camelus dromedarius) during different states of reproductive activity, was the subject of much speculation but of very little knowledge. An account of the anatomy and histology of the fermale dromedary gonads was given by TAYEB (1948). SHALASH (1965) described the ovaries of she-camels as well as the cyclic structures, including Graffian follicles and corpora lutea. ABDO et al. (1969) studied both the micro- and macroscopic properties of the camel ovary and concluded that although the shape, size and weight may differ from those of other species like cow, sow and mare, the microscopic properties of both the Graffian follicles and corpora lutea, showed no clear differences. MUSA \& ABU-SINEINA (1978) and WILLIAMSON \& PAYNE (1978) concluded that most corpora lutea were observed only during pregnancy and that ovulation is non spontaneous, requiring copulation. They added that copulation apparently triggers the release of the gonadotrophins essential for ovulation to occur, approximately 36 hours latter. On the other hand, ABDO et al. (1969) and NAWAR et al. (1978) recorded that post -ovulatory corpora haemorrhagica and mature corpora lutea were seen in the ovary of non-pregnant she camels.

ELIAS et al. (1984 a) studied the peripheral blood levels of progesterorie in female camels during various reproductive stages. They، recorded that progesterone concentrations were $/ .0 .6 \mathrm{ng} / \mathrm{ml}$ in the examined females before mating, after which, progesterone values increased to $>1 \mathrm{ng} / \mathrm{ml}$ within 2-3 days. ELIAS et al. (1984 b) also determined oestradiol concentrations in the serum of female one-numped cameis during the various reproductive stages. They mentioned that serum concentrations of oestradiol increased at the beginning of follicular growth and that 2 peaks were noted on days 11 and 16 after PMSG injection, however by early pregnancy, oestradiol values decreased. EL-WISHY et ai. (1984) studied the changes in the levels of estrogen and progesterone in the blood of pregnant and non-pregnant she-camels. They observed that estrogen levels were least in non-pregnant heifers $(43.6 \pm 9.8 \mathrm{pg} / \mathrm{ml})$ and in pluriparous animals $(29.0 \pm 14.2 \mathrm{pg} / \mathrm{ml})$ and that follicular growth was accompanied by a substantial increase of estrogen level. They added that during pregnancy, the level of progesterone fluctuated considerably between animals $(0.19 \pm 0.05$ to $1.93 \pm 0.81 \mathrm{ng} / \mathrm{ml})$ irrespective of their age, stage of gestation or weight of the corpus luteum.

EL-BAGHDADY et al. (1990) stdied the patterns of serum progesterone and total oesterogen throughout the reproductive cycle in female dromedary. They found that the non-cyclic camels possessed high serum total oestrogens $(57.62 \mathrm{pg} / \mathrm{ml})$ and negligable serum progesterone $(0.15 \mathrm{ng} / \mathrm{ml})$. In oestrus camels, these figures were $162.86 \mathrm{pg} / \mathrm{ml}$ and $0.19 \mathrm{ng} / \mathrm{ml}$ for the two hormones, respectively. At early pregnancy, serum progesterone showed sharp increase to $3.01 \mathrm{ng} / \mathrm{ml}$ and a sharp increase in oestrogens level (484.14 ng/ml) was observed during the last month of pregnancy.

The present work was carried out to estimate the serum levels of oesradiol and progesterone hormones as related to the different cyclic structures in the ovaries of the female one humped camels (Camelus dromedarius).

Assiut Vet.MedJ. Vol. 25, No. 50, July, 1991. 


\section{OESTRADIOL AND PROGESTERONE IN CAMELS}

\section{MATERIAL and METHODS}

The material of the present work was collected from 15 adult living she-camels kept with the farmers at Bani-Adi area and from 28, adult she-camels slaughtered at Bani-Adi slaughter-house, Assiut Governorate (Table 1).

Table (1): Number and reproductive status of the examined living and slaughtered she camels.

\begin{tabular}{llccc}
\hline $\begin{array}{c}\text { Ovarian structures and } \\
\text { reproductive State }\end{array}$ & Living & Slaughtered & Notal \\
\cline { 2 - 5 } $1-\quad$ & Mature follicles & 4 & 8 & 12 \\
$2-\quad$ & Atretic follicles & 3 & 7 & 10 \\
$3-\quad$ Growing follicles & 3 & 4 & 7 \\
$4-\quad$ Corpora lutea : & 3 & 5 & 8 \\
& Pregnant & & 4 & 6 \\
& non pregnant & 15 & 28 & 43 \\
\hline
\end{tabular}

Concerning living camels, each she-camel was examined rectally and special attention was given to both ovaries for the presence of ovarian structures including small follicles, growing or mature follicles, corpora lutea and these findings were recorded. Blood sample was coliected, through jugular venipuncture, after rectal examination of each animal into sterile centrifuge tubes.

Blood samples were also collected before slaughtering by jugular venipuncture from slaughtered she- camels into sterile centrifuge tubes. All collected blood samples from living and slaughtered animals were transferred in a thermos -flask containing ice- cubes to the laboratory where they were centrifuged at 3000 r.p.m. for 15 minutes. Clear serum was separated by careful aspiration and stored at $-20^{\circ} \mathrm{C}$ until the time of the hormone assay.

After evisceration of slaughtered animals, ovaries and reproductive tract were transfered to the laboratory. Both ovaries were removed, stripped from the surrounding structures and examined grossly for the presence of different structures, as mentioned above with living animals. Uterine horns were opened and examined for the presence of any conceptus. In pregnant animals, the approximate age of the foetus was estimated according to the procedure of EL-WISHY et al. (1981).

Oestradiol and progesterone hormone assay was carried at the hormone- assay unit in the centeral laboratory, Factilty of Medicine, Assiut University. This was achieved using coat-A count oestradiol $17-B$ and coat-A count progesterone radioimmunoassay kits supplied by Diagnostic Product Corporation, U.S.A. and following the techniques of the manufacturer and ENGLAND et al. (1974) andELIAS et al. (1984 a).

Assiut Vet.Med.J. Vol. 25, No. 50, July, 1991. 


\section{ZAGHLOUL \& SHEHATA}

Statistical analysis of the obtained results was carried out following the procedures ofMINIUM and CLARKE (1982).

\section{RESULTS}

The results of the hormone assay of oestradiol and progesterone in both living and slaughtered she-camels are summarized in table (2).

Conerning oestradiol hormone in living she-camels, a significant $(P / 0.001)$ increase was observed in the serum of animals having mature follicles than in those with growing follicles or those with small atretic follicles. Although the average level of the hormone in the serum of animals with corpora lutea in their gonads (two of them were at late stage of pregnancy) was too high $(325.0 \pm 148.02 \mathrm{pg} / \mathrm{ml})$ than in those with mature follicles, the difference between them was non-significant statistically. In slaughtered she-camels, oestradiol level showed a significant $(P / 0.001)$ increase in the serum of animals with mature follicles than those with growing follicles and those with atretic foilicles in their ovaries. However, a significant $(P / 0.05)$ increase of the hormone level was cbserved in the serum of animals with corpora lutea ( 3 of them were ai late stage of pregnancy! than those with mature follicles.

Relating the serum level of progesterone hormone in living and slaughtered shecamels, a significant $(\mathrm{P} / 0.001)$ increase was observed in the sera of animals having corpora lutea than those with mature follicles or small atretic follicles. Moreover, a significant $(P / 0.05$ ) increase of the hormone level was detected in the serum of slaughtered animals having mature follicles than those with smail follicles in their ovaries. On the other hand, no significant differences were found between living and slaughtered she-camels concerning the serum levels of both hormones.

\section{DISCUSSION}

Instead of oestrus cycles comparable to those of spontaneous ovulators, she-camel exhibits follicular cycles, with follicles developing and regressing successively and ovulation will occur only when mating has taken place (XU et al., 1985). CHEN et al. (1983) and Chen et al. (1985) demonstrated that ovulation is induced by some components of the seminal plasma. Moreover, EL-WISHY et al. (1981) revealed that successful fertilization is accompanied by maintenance of a large functioning corpus luteum.

The results of the present work indicated that oestradioi level in the serum of both living and slaughtered she-camels was markedly related, not only to the presence of follicular activity in the ovaries, but also to the size and the state of the present follicles. Animais with mature follicles (average diameter about $10 \mathrm{~mm}$ ) in their ovaries expressed higher levels of the hormone in their sera $(75.0 \pm 2.74$ and $80.0 \pm 2.32 \mathrm{pg} / \mathrm{ml}$ in living and slaughtered animals, respectively). Statistica!ly significant $(P / 0.001)$ difference was obvious on comparison of the hormone level in the sera of the above animals and those having growing follicles ( $3-5 \mathrm{~mm}$ in diameter) or smail atretic follicles (less than $2 \mathrm{~mm}$ in diameter). Nearly similar findings were recorded 


\section{OESTRADIOL AND PROGESTERONE IN CAMELS}

by EL-WISHY et al. (1984), who revealed that the least estrogen levels were noted when the ovaries of heifers or pluriparous camels $(43.6 \pm 9.8$ and $29.0 \pm 14.2 \mathrm{pg} / \mathrm{ml}$, respectively) contained atretic organized follicles. They added tht in the presence of small foilicles $(3-5 \mathrm{~mm}$ ), estrogen levels increased to $105 \pm 25.5$ in heifers and 168.02 $\pm 59.4 \mathrm{pg} / \mathrm{ml}$ in pluriparous camels. On the other hand, higher levels of oestrdiol were recorded by ELIAS et al. (1985) who found that 2 peaks of the hormone level (about $300 \mathrm{pg} / \mathrm{ml}$ were noted on days 11 and 16 in the sera of she-camels injected with 7000 I.U. of PMSG for induction of oestrus during seasonal anoestrus Conversly, lower values of oestradiol concentrations in the peripheral plasma of she-camels were reported by $\mathrm{XU}$ et al. (1985). They mentioned that the hormone levels were $26.8 \pm 9.0 \mathrm{pg} / \mathrm{ml}$ during the follicular phase and $30.8 \pm 5.1 \mathrm{pg} / \mathrm{ml}$ when the follicle was maximum size and these values fell after ovulation.

Moreover, the results of the present work showed a marked elevation of the hormone levels in the sera of she-camels having well- developed corpora lutea, particularly those animals which were at late stage of pregnancy (both living and slaughtered). This finding coincided with the findings of AGARWAL et al. (1987) and EL BAGHDADY et al. (1990), who revealed that oestrogen concentration in the pregnant camels tended to peak before parturition. They suggested that in camels like other ruminants, near the end of pregnancy, the placenta appears to switch solely to oestrogen synthesis, as it was recorded by WILLIAMS and GROSS (1986).

Concerning progesterone concentrations in the sera of both living and slaughtered animals, the obtained results revealed that there was a marked increase of the hormone levels in the sera of she-camels having functioning corpora lutea than those having other structures in their ovaries. Nearly the same trend of behaviour of progesterone hormone in the sera of she-camels was previously recorded by $X U$ et al. (1985). They revealed that during the follicular phase, peripheral plasma progesterone values were low $(0.36 \pm 0.28 \mathrm{ng} / \mathrm{ml})$, but values increased to reach $1.37 \pm 0.74 \mathrm{ng} / \mathrm{ml}$ at 3 days and $2.4 \pm 0.86 \mathrm{ng} / \mathrm{ml}$ at 7 days after ovulation. Moreover, EL-BAGHDADY et al. (1990) mentioned that concenterations of progesterone in the non-cyclic camels were $0.15 \pm 0.01 \mathrm{ng} / \mathrm{ml}$ and they were $0.19 \pm 0.02 \mathrm{ng} / \mathrm{ml}$ in cyclic camels at oestrus "follicular phase". They added that these values increased to $3.01-3.24,2.17-2.11$ and 2.28-2.86 $\mathrm{ng} / \mathrm{ml}$ during first, second and third trimester of pregnancy "luteal phase", respectively. On the other hand, ELIAS et al. (1985) found that serum levels of progesterone were less than $0.6 \mathrm{ng} / \mathrm{ml}$ in non-cyclic and in animals induced for oestrus (during oestrus phase). These values exceeded $1 \mathrm{ng} / \mathrm{ml}$ (from 3 to $7 \mathrm{ng} / \mathrm{ml}$ ) within $2-3$ days after mating of these she-camels. Meanwhile, EL-WISHY et al. (1984) reported that progesteione conterit of the blood of non-pregnant camels was always low $(0.037 \pm$ 0.01 to $0.17 \pm 0.09 \mathrm{ng} / \mathrm{ml}$ ) except in the presence of active corpora lutea of infertile services $(0.44 \pm 0.15 \mathrm{ng} / \mathrm{mil})$. They added that the hormonal level in the blood of pregnant camels was $0.19 \pm 0.05$ to $1.93 \pm 0.81 \mathrm{ng} / \mathrm{ml}$. These differences in the hormone level between the obtained results and the previously recorded results by other authors might be attributed to variations between the examined animals, steroids content in

Assiut Vet.Med.J. Vol. 25, No. 50, July, 1991. 


\section{ZAGHLOUL \& SHEHATA}

their sera, stage of sampling, state of activity of the corpus luteum and the reproductive future of the induced ovulation whether was followed by fertile (pregnancy) or infertile service (short luteal phase with regressive changes in the corpus luteum).

Finally it can be concluded that hormonal assay of oestradiol and progesterone in the peripheral blcod of she-camels can be used for confirmation of the rectal findings and determination of the optimum time for service or insemination, as a step on the way of improvement of reproductive performance of this animal.

\section{ACKNOWLEDGEMENT}

The kind and great help of professor Ahmed Nassar of the Department of Biochemistery, Assiut University is highly appreciated.

\section{REFERENCES}

Abdo, M.S.; Al-Janabi, A.S. and Al-Kafawi, A.A. (1969) Studies on the ovaries of the female camel during the reproductive cycle and in conditions affected with cysts. Cornel! Vet. 59, 418-425.

Agarwal, S.P.; Khanna, N.D.; Agarwal, V.K. and Dwaraknath, P.K. (1987): Circulatory levels of oestrogen and progesterone in female camel (C.dromedarius) during pregnancy. Theriogenology, 28(6), 849.

Chen, B.X.; Yuen, Z.X.; Pan, G.W.; Huang, Y.M. and Gao, Y.H. (1983): Studies on the ovulation mechanism in the bactrian camel. 11 the role of semen in induction of ovulation. Act.a Vet. Zootech. Sin. 14, 161-166.

Chen, B.X.; Yuen, Z.X. and Pan, G.W. (1985): Semen-induced ovulation in the bactrian camel (Camelus bactrianus). J. Reprod. Fert. 74, 335-339.

El-Baghdady, Y.R.M.; Hemeida, N.A.; El-Belely, M.S.; Abou-Ahmed, M.M. and Grunert, E. (1990): Serum profile of progesterone and oestrogens throughout the reproductive cycle of the female camel (C.dromedarius). Proc. 4th Sci. Cong. Fact. Vet. Med. Assiut University, 499-509.

Elias, E.; Bedrak, E. and Yagil, R. (1984 a): Peripheral blood levels of progesterone in female camels during various reproductive stages. Gen. Com. Endocr. 53, 235-240.

Elias, E.; Bedrak, E. and Yagil, R. $(1984$ b): Oestradiol concenteration in the serum of the one-humped camel (Camelus dromedarius) during the various reproductive stages. Gen. Com. Endocr. 56: 258-264.

Elias, E.; Bedrak, E. and Cohen, D. (1985): Induction of vestrus in the camel (Camelus dromedarius) during seasonal anoestrus. J. Reprod. Fert. 74: 519-525.

El-Wishy, A.B.; Hemeida, N.A.; Omar, M.A.; ivobarak. M.A. and Ei-Sayed, M.A.l. (1981): Functional changes in the pregnant camel with special reference to foetal growth. Brit. Vet. J. 137: 527-537.

El-Wishy, A.B.; Hemeida, N.A.; El-Sayed, A.A.; Seida, A.M.; Ghallab, A.M. and Reimers, T.j. (1984): Estrogen and progesterone levels in the blood of pregnant and non-pregnant camels (camelus dromedarius). J. Mii. 5, 39-49. 


\section{OESTRADIOL AND PROGESTERONE IN CAMELS}

England, B.G.; Niswender, G.D. and Midgley, A.R. (1974): Radioimmunoassay of estradiol 17-B without chromatography. J. Clin. endocrinol. 38: 42-50.

Minium, E.W. and Clarke, R.B. (1982): Elements of Statistical Reasoning. 1st Ed. John. Willey \& Sons Inc., New York.

Musa, B.E. and Abu-Sineina, M.E. (1978): The oestrus cycle of the camel (camelus dromedarius). Vet. Rec. 103, 556-557.

Nawar, S.M.A.; Abul-Fadel, W.S. and Mahmoud, S.A. (1978): Studies on the ovarian activity of the dromedary (camels dromedrius). Z.mikrosk. Anat. Forsch. Leipzig 92: $385-408$.

Shalash, M.R. (1965): Some reproductive aspects in the female camel. world Rev. Anim. Prod. 4: 103-108.

Tayeb, M.A.F. (1948): Studies on the anatomy of the ovary and corpus luteum of the camel. Vet. J. 104: 179-186.

Williams, W.F. and Gross, T.S. (1986): In vitro placental steroid synthesis in the late pregnant and pre-partum cows. Biol. Reprod. 34 (suppl. 1), 77.

Williamson, G. and Payne, W.J.A. (1978): An Introduction to Animal Husbandry in the Tropics. 3rd Ed. Longman, London.

Xu, Y.S.; Wang, H.Y.; Zeng, G.Q.; Jiang, G.T. and Gao, Y.H. (1985): Hormone concentrations before and after semen induced ovulation in the bactrian camel (camelus bactrianus) J. Reprod. Fert. 47: 341-346. 


\section{ZAGHLOUL \& SHEHATA}

Table (2): Serum levels of oestradiol and progesterone of living and slaughtered she-camels in relation to ovarian structures.

\begin{tabular}{|c|c|c|c|}
\hline Ovarian structures & $\begin{array}{l}\text { No. of } \\
\text { animals }\end{array}$ & $\begin{array}{l}\text { Destradiol } \\
(\mathrm{pg} / \mathrm{ml})\end{array}$ & $\begin{array}{l}\text { progesterone } \\
\text { ( ng, }(\mathrm{ml})\end{array}$ \\
\hline
\end{tabular}

1- Mature follicles

$\begin{array}{llll}\text {-Living animals } & 4 & 75.00 \pm 2.74 & 0.143 \pm 0.004 \\ \text {-Slaughtered.. } & 8 & 80.13 \pm 2.82 & 0.173 \pm 0.014\end{array}$

2- Airetic follicles

-living animals 3

$22.67 \pm 4.37^{* * *} 0.140 \pm 0.003$

- Sl aughtered.. 7

$23.57 \pm 2.33^{* * *} \quad 0.137 \pm 0.003^{*}$

3- Growing follicles.

-Living animais 3

$40.67 \pm 2.73^{* * *} 0.150 \pm 0.020$

-Sl aughtered.. 4

$51.00 \pm 2.55$

$0.177 \pm 0.005$

4-Cornoria l litea

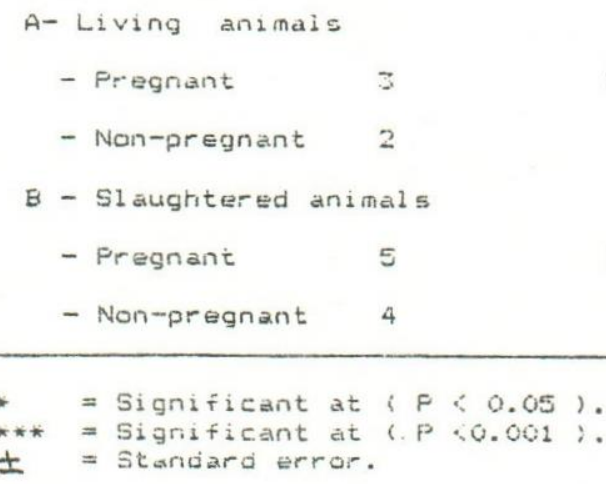

Assiut Vet.Med.J. Vol. 25, No. 50, July, 1991. 